\title{
Science teacher education program for effective classroom performance in a changing world
}

\author{
Daniel Patrick, Banu; Sadiq Abubakar, Abdullahi \\ Department of Education, Federal University, Kashere, Gombe, Nigeria \\ Email address: \\ Danielbanu2000@yahoo.com (D. P. Banu), aabdu101@yahoo.com (S. A. Abdullahi)
}

To cite this article:

Daniel Patrick, Banu; Sadiq Abubakar, Abdullahi. Science Teacher Education Program for Effective Classroom Performance in a Changing World. International Journal of Science, Technology and Society. Vol. 2, No. 4, 2014, pp. 78-84.

doi: $10.11648 /$ j.ijsts.20140204.14

\begin{abstract}
One of the challenges in science teacher education program in universities and colleges of education around the world is preparing pre-service teachers to teach effectively from a global perspective. Adding a global dimension in a science classroom helps students to develop global knowledge and understanding, and a cosmopolitan spirit needed for the twenty-first century global citizenship. This paper discusses how Department of Education at Federal University Kashere, Nigeria, attempts to prepare its pre-service science teachers to add a global dimension in the classroom to prepare students for global competitiveness and global citizenship. The teacher education program adheres strictly to national and international standards and to best instructional practices.
\end{abstract}

Keywords: Science Teacher Education, Global Dimension, Secondary Science Program

\section{Introduction}

As changes in science and technology and the effect of globalization force institutions of higher education to rethink and review program effectiveness and its impact on enrollment, which may come from all parts of the globe, the Department of Education at the Federal University Kashere, Nigeria, created in 2012, is attempting to add a global dimension as it prepares pre-service science teachers to develop a global perspective and teach effectively as global citizens in order to compete effectively in the global market place.

The science teacher education program provides the nucleus for developing an institutional framework for the effective teaching of science at the primary and secondary schools. The preparation of pre-service science teachers becomes critical as the vision of the $21^{\text {st }}$ century classroom requires that universities and colleges of education adhere to high national and international standards and accomplished practices.

In the United States, the National Research Council (NRC), the American Association for the Advancement of Science (AAAS), and the Common Core Initiative (CCI) are now collaborating to respond to globalization and are urging higher education institutions to add a global dimension in their programs. The National Science
Teachers' Association (NSTA) in Nigeria and the Science Teachers Association of Nigeria (STAN, 1973) are also recommending the review of science education programs to meet national and international standards and best instructional practices. Even the Nigerian Universities Commission (NUC, 2011) is following suit and has issued a directive to universities to internationalize their programs and activities.

Consequently, if Nigeria hopes to meet the Millennium Development Goals \#1 by 2015 and the Vision 20:2020 aspiration of the nation to become one of the top 20 most industrialized nations, science education program must contribute by preparing teachers to be effective in the classroom. Globalization, modernization, and industrialization need competent individuals who have acquired scientific and technological competencies, skills, and disposition to compete with the best in the world (Banu, 1992).

\section{Historical Context}

The introduction of science education in Nigeria dated back to the 1859 when the Christian missionaries first began to explore the idea of spreading Christianity to save those they perceived as "heathen" and "backward." The school curriculum was one way of spreading the message 
of Christianity. By the late 19th century, when the scramble for Africa was intensified and the region partitioned, there was the need to set up schools to meet the growing demands of the time. Olorundare and Omosewo (2011) believed that Western education brought into Nigeria by the missionaries in 1843 sets the foundation for the learning of science in primary schools. The first primary school with a science curriculum was established in Badagry, Nigeria. Similarly, the Church Missionary Society School, Lagos, Nigeria also established the first secondary school with upper level science curriculum in 1859.

By 1934, the Yaba Higher College provided the curriculum for science education in courses in agriculture, medicine, engineering, and survey, paving the way for the University of Nigeria, Nsukka 1959 started to offer science degree programs. Ahmadu Bello University in Zaria in 1962, University of Lagos in 1962, Obafemi Awolowo University, Ile-Ife in 1962, and University of Ibadan, as early as 1948 as College of University of London, offered degrees in science courses. Other universities such as the University of Jos, University of Ilorin, University of Calabar, University of Sokoto, and University of Maiduguri began offering degree programs in science leading to Bachelor's degree in Chemistry, Physics, Botany, Zoology, and Mathematics. As a consequence, the need to train teachers, particularly science teachers, for secondary schools emerged.

Since independence in 1960, most universities and colleges of education have struggled to train a number of science teachers for effective teaching of science in schools. However, there has been an unprecedented and prolonged failure to meet national and international standards, and mass failure in West African Examination Council (WEAC).

\section{Primary Science Education}

The primary goals of primary science education are to develop in students an enquiring mind and a scientific approach to problems and helping them to develop a culture of scientific thinking and scientific investigation. The African Primary Science Programme (APSP) first provided the framework for organizing the primary science curriculum in the 1960s. In the 1980s, the Federal Government of Nigeria published guidelines for teaching science in primary schools (Onwu, 2010) which universities and colleges of education have used to prepare pre-service science teachers. According to Onwu, the aims of the Core Curriculum for Primary Science Education for students are to:

- $\quad$ Observe and explore the environment;

- Develop basic science process skills such as observing, manipulating, classifying, inferring, hypothesizing etc.;

- $\quad$ Explain simple natural phenomena;

- Develop scientific attitudes including curiosity critical reflection and objectivity;

- Apply the skills and knowledge gained through science in solving everyday problems in the environment;

- Develop self-confidence and self-reliance through problem solving activities in science (Onwu, 2010).

Although, the Science Teachers Association of Nigeria (STAN) has never been pleased with how universities and colleges of education prepare pre-service teachers to teach science at the school level, the organization issued a statement of hope and encouraged stakeholders in science education to focus on improving pedagogical skills in science education (Onwu, 2010). Similarly, in the 1980s, the Nigerian secondary science school curriculum was modernized. Olorunde and Omosewo (2011) have identified seven areas of knowledge which existed in the area of science education. They include:

(a) Technology and Production

(b) Science and speculation

(c) Mathematics and calculation and

(d) Physical Education and Prowess.

The history of modern science teaching in Nigerian schools is comparatively recent. Unlike most Western countries where science teaching grew from the universities to high schools, in Nigeria science teaching has its roots in the primary schools. Western education was introduced to Nigeria in 1843 when the Methodist Mission established in Badagry the first known primary school. In making education available to the citizens, the missionary's major interest was to train evangelists and catechists who would assist the church in spreading the gospel in Nigeria. The same motive led the Church Missionary Society (CMS) in 1859 to establish the first secondary schools, the CMS Grammar School, Lagos, in Nigeria. Shortly afterwards, a number of secondary and teacher training institutions were founded. They include: the Western Methodist Boys High School, Lagos, St. Gregory's College, Lagos, the Methodist Girls' High School, Lagos, Kings' College, Lagos and Queens' College, Lagos. There was a shortage of science teachers, and this hampered students' performance at internal and external examinations. Added to the shortage of teachers were: (a) lack of science laboratories (b) lack of instructional objectives in science teaching (c) lack of funds to promote science teaching (d) lack of text books and (e) lack of uniform curriculum in science (Onwu, 2010).

But the appointment of Erick J. Hussey in 1929, as the first Education Commissioner, brought comprehensive reforms in science education throughout the country (Omosewo, 1991, 2008). In 1934, the Yaba Higher College was established to provide intermediate manpower for science teaching as well as other science based professions such as Agriculture, Medicine, Engineering and Survey. Some of the graduates of Yaba Higher College went to Universities to undergo Diploma courses in Education and Postgraduate Certificate in Education. Science education as a degree program did not begin at the universities. University of Nigeria, Nsukka was the first to introduce such a degree program. Other Universities such as Ahmadu Bello University Zaria (1962), Universities of Ibadan (1965), Lagos (1962), and Obafemi Awolowo University, 
Ile-Ife (1962) followed suit. These universities are now referred to as the first generation universities. There were other universities such as Lagos State University (LASU) and private universities that were considered late comers that had science education programs designed specifically for the training of teachers.

The role science education played in the development of a student and a nation cannot be overemphasized. The values, ethos, principles, practices and perspective of science for interpreting and understanding nature continue to be debated at national and international conferences. Adding a global dimension to the discussion in an era of high educational standards, best practices, and accountability adds value to science education programs around the world. Universities and colleges of education are now joining the globalization of the curriculum bandwagon as they internationalize their activities and programs. This gives them a marketing and promotional edge. We are, by no means, suggesting that science education programs have traditionally not infused a global dimension in their programs. We are suggesting that in a globalized changing world, science teacher education must add a global dimension. As science education students consider themselves as global citizens, they contribute more scientifically and technologically in securing the Planet (Abdullahi, 2014).

If the current global trends and issues in science teacher education continue, the technological advancement, scientific creativity and innovations, and the forces of globalization (economic, political, military, social, environmental, and educational), Science Teachers' Association in collaboration with the Federal Ministry of Education (FME) should respond by reviewing its current standards to meet international standards and the needs of the nation. The development in telecommunications, communications technology and computer technology, and e-banking technology is forcing nations to rethink their educational system with emphasis on science, technology, engineering, and mathematics.

\section{Challenges in Science Teacher Education}

According to Banu (1992), one of the challenges facing science education program in Nigeria for the 21 st century is preparing science teachers to be effective practitioners in the age of globalization. One of the trends in teacher education in the United States is preparing pre-service teachers to teach to the expected state standards. Teacher accountability is forcing teacher quality and effective teaching and learning in the classroom, as many state governments are moving towards the Common Core State Standards (Common Core Initiative, 2013).

Olorundare and Omosewo (2011) believed that there was shortage of science teachers, and this shortage greatly impacted on students' performance at internal and external examinations. They identifies the following challenges facing science education: (1) lack of science laboratories, (b) lack of instructional objectives in science teaching, (c) lack of funds to promote science teaching, (d), lack of text book, and (e) lack of uniform curriculum in science. By the mid- $20^{\text {th }}$ century, some of the challenges were partially resolved, but some still persist today as new challenges emerged. Furthermore, they believed that one of the most important challenges in science education today is the "derivation of content and appropriate methodologies..." Some of the challenges include entry qualification of those who want to teach science, methods of training and insufficient qualified instructors, and exposure to first class laboratory tools.

The Science Teacher Education program at Kashere will ensure the inculcation of a value system appropriate to a career in teaching, the imparting of specific knowledge, new skills, knowledge, and creativity, and the retraining of teachers through in-service education to enable them to pace with new trends in science education. Additionally, to cope with challenges of the $21^{\text {st }}$ century in science teacher education programs globally with international standards and best practices, the Kashere program will equip the student teachers with Information Communication Technology (ICT) skills to continue acquiring new skills, knowledge and dispositional.

The preparation of pre-service science teachers for the 21 st century poses a more difficult challenge especially in Africa. In Nigeria, the Federal Government, through the Federal Ministry of Education has embarked on an ambitious plan to correct the science and technology education challenges (FME, 2010). Historically, the British colonial master plan as well as its policy on education in Nigeria was devoid of vocational and technical education. This is understandable as the intent of the British was to offer education for the gentleman and clerks rather than producing technically-trained people needed for the economic development of Nigeria.

Three of the recommendations in the Federal Ministry of Education 10 Years Strategic Plan are to revitalize technical and vocational education and training (TVET), the need to focus on entrepreneurial and skill training, and the realignment of curricula to meet the emerging needs of the global economy and knowledge society. Science and technology became means to achieving the first objective. Accordingly, science teacher educators believe that if the nation hopes to meet the Education for All (EFA) goals, the Millennium Development (MDGs) goals, and the Vision 20-2020 goals, the teaching of science teachers in our universities and in our colleges of education must be reevaluated.

\section{Science Teacher Education at Federal University, Kashere (FUK)}

The FUK's vision for the science teacher education 
program is linked to the institutional vision and mission (Academic Brief, 2011). As indicated earlier, in 2011, the Federal Government of Nigeria, created nine new universities in order to provide access and opportunity to the growing number of students who have passed the entrance examination to tertiary institutions in the country. One of the universities created was the Federal University Kashere (FUK) in Gombe State.

One of the goals of the Faculty of Education at FUK is to prepare students to be effective teachers in the classroom. The faculty has identified the following areas of emphasis: (1) Mastery of teaching subject, (2) Development of appropriate pedagogical skills for teaching science, (3) Development of effective communication skills, (4) Critical thinking and ethics, (4) Competency in information communication technology (ICT), (5) Global education, (6) Entrepreneurial and service learning, and (7) Mastery of laboratory management skills as important component of the education program.

The Vice-Chancellor, Professor Mohammed K. Farouk, a distinguished professor from Florida International University, Miami, Florida in the United States of America became the pioneering vice-chancellor. Some of the expectations of FUK include providing the highest quality service, the highest quality educational environment, the best curriculum and instruction, and the best graduates, while creating national and international opportunities for staff and students.

Omosewo (1998) found that senior secondary school physics teachers in Kwara state, Nigeria, who took the external examination in science, did not posess adequate knowledge to interpret correctly the performance objectives of the senior secondary physics curriculum. In 2001, Omosewo also found that teachers who taught physics at the senior secondary school could not completely teach a lesson or design a unit. She attributed this deficiency to colleges of education and universities inability to adequately prepare teachers to teach science effectively in the classroom.

The program at Kashere endorses John R. Stavey (2012) observation that science teacher education program has certain principles and values. These values and principles include:

- $\quad$ Teaching as a purposeful means to an end. Pre-service science teachers should think of science teaching as a purposeful means to an important goal;

- Core scientific ideas. Pre-service science teachers should concentrate on the core scientific ideas that have the greatest importance;

- Deep scientific understanding. Pre-service science teachers should promote deep scientific understanding through teaching that mirrors the nature and characteristics of inquiry in science, the values of science, and the body of scientific knowledge;

- Complexity of learning. Pre-service science teachers should be aware of the level of complexity when designing and teaching science lessons, and should consider the complex interaction between learners biological maturation prior knowledge and experience, and reasoning abilities, so that the lessons challenge students but do not overwhelm learners cognitive capabilities.

- Active construction of scientific knowledge. Preservice science teachers should teach with strategies and techniques that learners become active thinkers;

- Science content and students interests. Pre-service science teachers should connect science content with students' interest and personal lives, with societal issues and with other school subjects;

- Expectations for learning. Pre-service science teachers should set high expectations for all students; and

- Students' anxiety and conflicts. Pre-service science teachers should use teaching strategies that lessen students' potential anxieties and perceived conflicts when teaching scientific ideas that may be controversial for learners.

\section{The Science Education Program at FUK}

The Science Teacher education program at FUK will ensure that it has the following characteristics as identified by Leu, Hays et al (2005):

- Knowledge of the relevant subject matter,

- Use of a range of pedagogies appropriate for the content,

- Competence in the language of instruction,

- Ability to create and sustain an effective learning environment,

- Recognition of and response to the needs and interest of students and community,

- Habitual reflection on their teaching and students' responses and changing the learning environment accordingly,

- Developing strong sense of ethics and professionalism and commitment to teaching, and

- $\quad$ Caring about their students (Leu, Hays et al 2005).

Staver (2012) offered some specific expressions of the beliefs and dispositions of effective science teachers. He observed that effective science teachers should believe and act as follows:

- Respect and accept the unique perceptions of individual learners.

- $\quad$ Reflect on and consider learners' prior knowledge and interests when selecting and using specific teaching strategies and techniques.

- Believe that all students can and will learn.

- Create a challenging, but non-threatening growth of all learners.

- Commit to the learning and intellectual growth of all learners.

- View one as capable, dependable, and generally positive. 
- Believe that one can teach effectively and that effective teaching will lead to positive learning outcomes.

Staver (2012) observed that effective science teachers work together and align their work with appropriate science standards. They identify the core ideas of the science discipline across all grade levels, decide the core scientific ideas to be taught, outline how core scientific ideas that are introduced, select science curricula that emphasize scientific inquiry as a method of teaching, maintain a high level of consistency among the goals and objectives, instruction, and assessment of each lesson, unit of instruction, course, and program.

Staver (2012) observed also that effective science teachers use techniques to promote deep scientific understandings when they determine if tasks are problems or exercises and ask students if they have a good idea or little-to-no idea how to do specific tasks, organize cooperative student groups that reflect intellectual, gender, and cultural diversity and have members of a group share and discuss their representations of the gap and proffered solution strategies, use guided-inquiry teaching strategies (e.g., Learning Cycle, 5-E Instructional Model) that lead learners to continue developing and modifying their knowledge, aim problem-solving instruction slightly beyond what students can do alone but within the boundaries of what they can do with assistance from others, use science concepts and processes as contexts for students to write persuasive theories; and solve problems requiring mathematical reasoning, design discussion and negotiations among students as on-going learning experiences, and provide opportunity for students to claim ownership of their learning.

Furthermore, Staver (2012) observed that effective science teachers use appropriate techniques in response to the complexity of learning when they give a pretest before starting a unit of instruction; use the results to learn what students know and do not know, and to plan appropriate lessons, use concrete, manipulative materials and familiar events to help students directly experience phenomena and to encourage their active construction of abstract concepts, ask a blend of high-level, low-level, open-ended, and closed-ended questions to activate students' thinking, wait at least three seconds after asking a question before rephrasing it, wait at least three seconds following a student's response to a question before continuing, delay including abstract science concepts with young children if these concepts cannot be introduced with concrete materials and familiar experiences, and aim the level of instruction slightly beyond the capabilities of individual learners but within the capabilities of groups of learners.

Staver (2012) also observed that effective science teachers use appropriate approaches to ensure that students are actively constructing their learning when they present science as a process of constructing and empirically testing models for their ability to explain and predict, devote time to diagnosing learners' alternative conceptions, employ a repertoire of teaching approaches that range from open and guided inquiry to direct instruction, use teaching strategies and assessment format that are consistent with the goals of the lesson, use teaching strategies that help learners become aware of inconsistencies I their thinking, use teaching strategies that raise students' awareness of how they construct knowledge together and as individuals, employ discrepant events to engage learners with concrete phenomena, activate their interest, and help them become aware of the conflicts between their thinking and accepted scientific concepts.

When determining the order in which to introduce science concepts in a given domain, consider the ways those concepts are interdependent, use teaching strategies that include familiar analogies, metaphors, and physical models to guide learners toward accepted scientific concepts, adapt available curriculum materials and teaching strategies to fit the diverse needs of all students, organize cooperative student learning groups that reflect intellectual, gender, and cultural diversity, and conduct frequent assessment as a seamless part of teaching and use the result to modify instructional experiences for groups and individual learners.

Again, Staver (2012) observed that science teachers use appropriate techniques to connect with students interests when they connect science concepts and instruction explicitly to learners' personal experiences, use specific examples, analogies, and metaphors, plan lessons to emphasize themes of science, technology, and society, have students organize data into diagrams, tables and graphs, have students use data in tables and graphs (bar, line, and histogram) to identify patterns and make predictions, have students use mathematical operations, fractions, decimals and percentages to calculate results of investigations, have students read passages in science texts and trade books and identify major and minor ideas, summarize what they have read, and make predictions, have students develop and role play scenes in which they use scientific thinking or play the roles of scientists.

Staver (2012) observed that effective science teachers use appropriate strategies to maintain high expectations when they monitor and analyze students' work and take corrective individual and group action as needed, help students believe in their ability to learn effectively and to raise their awareness of positive outcomes as a result, help students view themselves as capable learners, build learners confidence by breaking difficult tasks into smaller steps that they view as more manageable and achievable, provide assistance but do not do tasks for students, give learners a reasonable level of control over their learning, help learners become aware that their own efforts, strategies, and persistence are important to their successful learning, and help learners experience the satisfaction of successful learning.

Finally, Staver (2012) observed that effective science teachers use appropriate strategies to address students' anxieties and conflicts when they are sensitive to students' 
verbal and nonverbal behavior when teaching a unit that students may perceive as containing controversial ideas, clarify the difference between understanding and believing, use peer-group discussion to help students become aware of other students' thoughts about the concept, avoid using words such as "true" and "believe" in reference to science concepts, emphasize the explanatory power and predictive ability of a concept, encourage students to think about concepts as tools for solving scientific problems, and point out how a concept or theory may benefit individuals, society and the environment.

\section{Science Teachers as Global Citizen}

Aram and Levon Aghasyan at the Faculty of Biology, Yerevan State University and researchers in the Institute of Zoology of National Academy of Sciences of Armenia believe that science teachers could indeed become a global citizens. Consequently, after going through the Kashere Science Education program, successful candidates should be able to prepare their students to think globally and acting locally as scientists. Some of the challenges that science teachers will face are infusing the elements of global citizenship curriculum in their lessons, and the lack of understanding the scope and nature of global citizenship. Global citizenship requires students to develop an identity and a consciousness or a perspective that stresses natural and humanistic tendencies and norms. Global interdependence, interconnectedness, collaboration, and partnerships that stretch beyond national, regional, ethnic, and racial boundaries are some of the characteristics of global citizenships.

Global citizenship and science education can transform students' global consciousness and their perceptions of themselves, other cultures, and other nations. National and international laws and policies, accomplished national and international practices, activities, and programs are acknowledged and respected. They strive to foster a global perspective, global understanding, and global cooperation through scientific discovery and delivery. Global citizenship education is a global holistic development paradigm or perspective.

\section{Conclusion}

Science education provides the foundation for all scientific discoveries and innovations. Science teacher education program in universities and colleges of education should prepare pre-service teachers to teach from global perspective. By adding a global dimension in the classroom, students develop global understanding and a cosmopolitan spirit needed for the twenty-first global citizenship. Students are prepared to compete effectively in the global community. All teacher education programs should adhere to strict national and international standards and to best instructional practices.

\section{References}

[1] Abdullahi, S. A. (2010). Rethinking global education in the Twenty-first century. In J. Zajda (Ed.). Global pedagogies: schooling for the future (pp. 23-34). Dordrecht, New York: Springer.

[2] Abdullahi, S. A. (2008). The Hope for Nigeria: Vision 2020 Faces Difficult Challenges Ahead. The Nigerian Economic Summit Group. NESG Economic Indicators, pp 40 -46, JulySeptember.

[3] Abdullahi, S. A. (2007). "Education and democracy in Nigeria: Vision 2020." Retrieved December 15, 2013 from http://www.nigeriainamerica.com/articles

[4] Abdullahi, S.A. (2004). Teacher's knowledge, awareness, and pedagogy of global education in secondary schools. Unpublished doctoral dissertation, Florida International University, Miami, FL.

[5] Ajaja. O. P. (2009). Evaluation of science teaching in secondary schools in Delta State 2-teaching of the sciences. International Journal of Science, 1 (2) 119-129.

[6] Ajeyelemi, D. (1987). Science education in the last Two Decades: Are We Really Serious. In ejiogu, A.M. \& Ajeyalemi, D. (eds) Emergent Issues in Nigerian Education. Lagos, jaja Ed. Res. Publishers, p. 147-159.

[7] American Association for the Advancement of Science. (AAAS, 1989). Science for all Americans. Washington: AAAS.

[8] Banu, P. (1992. Trends in the goals and objectives of science education. Journal of Science Teachers' Association of Nigeria, vol 27 (2) pp 25-29.

[9] Ben, B.A (2010). Innovations in science and technology education through science teacher associations. Science Education International 21 (2) 67-79.

[10] Dr. Mohamad H. Atyeh, Prof. Wael Al-RashedTesting the Existence of Integration; Kuwait and Jordan Financial Markets International Journal of Economics, Finance and Management Sciences MMDD-2013, pp. 89-94. doi:10.11648/j.ijefm.20130102.14

[11] Federal Ministry of Education. (FME, 1985). National core curriculum for junior secondary schools. Lagos: Federal Government Press.

[12] Federal Ministry of Education. (FME, 1982). National core curriculum for senior secondary schools. Lagos: N.E.R.D.C.

[13] Federal Government of Nigeria. (1981). National policy on education (2nd edn). Lagos. Government Press.

[14] Federal University Kashere, Gombe, Nigeria: Academic Brief, 2011

[15] Ojimba P. D. (2013). Enhancing schools - industries partnership in science education: Implications for Nigerian secondary schools. European Scientific Journal, vol 9, no 13.

[16] Olorundare, A. S. (2010). The need for a reform in the STEM teacher education. A paper presented during the Kwara State conference of STAN at the University of Ilorin Auditorium. 
[17] Olorundare, A.S., \& Omosewo, E.O. (2011). Trends and issues in science teacher education in Nigeria and the way forward. A paper presented at the $2^{\text {nd }}$ International Conference of the Collaboration of Education Faculties in West Africa (CEFWA) in the Faculty of Education at the University of Lagos, Nigeria.

[18] Omosewo, E.O (1991). Relevance of the physics education programme of Nigerian Higher Institution to the teaching of secondary physics in published $\mathrm{PhD}$ thesis, Unilorin.

[19] Omosewo, E.O (1998). A proposal for an improved training programme for prospective physics teachers in Nigeria secondary schools. Science Education Forum 2, 36-41.

[20] Onwu, G. O. (2010). Science in Nigerian Secondary Schools: What Went Wrong. Retrieved
[21] Opateye, J.A. (2012). Nigeria secondary school science teachers' awareness and preparation for the challenges of Vision 20:2020. Africa Research Review, vol 6 (4), (27)

[22] Staver, J.R. (2012). Teaching science. Educational practices series-17. International Academy of Education. http:/www.curtin.edu.au/curtin/dept/smec/iae

[23] STAN. (1973). Constitution of the Science Teachers Association of Nigeria. Ibadan: STAN

[24] STAN. (1992). Raising the standard of performance in public examinations in science, technology and mathematics. Position paper No. 4.Ibadan: STAN 